\title{
Uterine secretion of prostaglandin F2 $\alpha$ stimulated by different doses of oxytocin and released spontaneously during luteolysis in cattle
}

\author{
Jan Kotwica ${ }^{\text {a*}}$, Dariusz Skarzynski ${ }^{\mathrm{a}}$, Jerzy Jaroszewski ${ }^{\mathrm{a}}$, \\ Gary L. Williams ${ }^{\mathrm{b}}$, Marek Bogacki ${ }^{\mathrm{a}}$ \\ ${ }^{\text {a }}$ Institute of Animal Reproduction and Food Research, Polish Academy of Sciences, \\ 10-718 Olsztyn-Kortowo, Poland \\ ${ }^{b}$ Animal Reproduction Laboratory, Texas Agricultural Experiment Station, \\ The Texas A\&M University System, Beeville, TX 78102, USA
}

(Received 6 January 1998; accepted 11 May 1998)

\begin{abstract}
The objectives were to determine the involvement of oxytocin (OT) in the stimulation of prostaglandin F2 $\alpha$ (PGF) secretion during luteolysis in cattle. On days 16-17 of the oestrous cycle, catheters were inserted into the aorta abdominalis of heifers for OT or saline infusion and into the jugular vein for blood sample collection. The following day, heifers were assigned to one of three experimental groups (Gr): Gr I - 10 IU OT $(n=4)$; Gr II - 20 IU OT $(n=4)$; Gr III - 50 IU OT $(n=4)$. Blood samples were collected every 10 min during a 1-h control period before treatment and every 5-10 min for $2 \mathrm{~h}$ after OT treatment. In Gr IV $(n=5)$, a catheter was inserted into the jugular vein on day 15 of the cycle and blood samples were collected every $15 \mathrm{~min}$ for $12 \mathrm{~h}$ on days 16-19. Plasma concentrations of progesterone, PGF metabolite, 13, 14-dihydro-15-keto-prostaglandin F2 $\alpha$ (PGFM) and OT were determined. Within 5 min of infusion of 10 or 20 IU OT, peripheral concentrations of OT $(7-12 \mathrm{pg} / \mathrm{mL})$ increased by about 200 and $350-500 \mathrm{pg} / \mathrm{mL}$, respectively. These doses did not affect plasma concentrations of PGFM or progesterone within $1.5 \mathrm{~h}$. Fifty IU of OT increased its maximal peripheral concentration to $1500 \mathrm{pg} / \mathrm{mL}$, which is over 20 times greater than that observed physiologically. Concentrations of plasma PGFM in Gr III increased from basal concentrations $(50-65 \mathrm{pg} / \mathrm{mL})$ to $150-250 \mathrm{pg} / \mathrm{mL}$ $(P<0.01)$ within $10-30 \mathrm{~min}$. During luteolysis, PGFM pulses ranged between 250 and 600 $\mathrm{pg} / \mathrm{mL}$ on days $16-19$ of the cycle (Gr IV), whereas coincident pulses of OT, and those appearing between spikes of PGFM, were never above $75 \mathrm{pg} / \mathrm{mL}$. Only $50 \%$ of OT pulses coincided with pulses of PGFM, and $54 \%$ of PGFM pulses coincided with a pulse of OT. Results indicate that luteolytic PGF secretion in cattle is not directly dependent upon ovarian OT. (O) Inra/Elsevier, Paris
\end{abstract}

oxytocin / progesterone / luteolysis / prostaglandin F2 $\alpha$ / corpus luteum / cattle

\footnotetext{
* Correspondence and reprints

E-mail: janko@food.irzbz.pan.olsztyn.pl
} 
Résumé - Sécrétion utérine de prostaglandine F2- $\alpha$ stimulée par différentes doses d'ocytocine, et libérée spontanément durant la lutéolyse chez les bovins. Les objectifs étaient de déterminer le rôle de l'ocytocine (OT) sur la régulation de la sécrétion de prostaglandine F2- $\alpha$ (PGF) pendant la lutéolyse chez les bovins. Aux jours 16 ou 17 du cycle œstrien, des cathéters étaient insérés dans l'aorte abdominale de génisses pour infuser de l'OT ou du sérum physiologique, et dans la veine jugulaire pour collecter des échantillons de sang. Le jour suivant, les génisses étaient réparties au hasard dans un des trois groupes (Gr) expérimentaux : Gr I -10 UI OT $(n=4)$; Gr II - 20 UI OT $(n=4) ;$ Gr III -50 UI OT $(n=4)$. Des échantillons de sang étaient collectés toutes les $10 \mathrm{~min}$ pendant une période témoin de $1 \mathrm{~h}$, et toutes les 5-10 min pendant $2 \mathrm{~h}$ apès le traitement OT. Dans le Gr IV $(n=5)$, un cathéter était placé dans la veine jugulaire le quinzième jour du cycle et des échantillons de sang étaient collectés toutes les 15 min pendant $12 \mathrm{~h}$ aux jours $16,17,18$ et 19 du cycle. Les concentrations plasmatiques de progestérone, de 13, 14-dihydro-15-citoprostaglandine F2- $\alpha$ (PGFM) et d'OT ont été mesurées. L'infusion de 10 ou 20 UI d'OT augmente les concentrations périphériques d'OT qui atteignent environ 200 et $350-500 \mathrm{pg} / \mathrm{mL}$ en $5 \mathrm{~min}$. Ces doses n'affectent pas en revanche les concentrations plasmatiques de PGFM ou de progestérone. Une dose plus élevée d'OT (50 UI) porte la concentration périphérique maximale de $1500 \mathrm{pg} / \mathrm{mL}$, ce qui est plus de 20 fois supérieur à celle observée physiologiquement. Dans le Gr III, les concentrations plasmatiques basales $(50-65 \mathrm{pg} / \mathrm{mL})$ de PGFM augmentent jusqu'à $150-250 \mathrm{pg} / \mathrm{mL}(P<0,01)$ en $10-30 \mathrm{~min}$. Durant la lutéolyse, des pulses de PGFM atteignant des niveaux de $250-600 \mathrm{pg} / \mathrm{mL}$ étaient détectés entre j 16 et $\mathrm{j} 19 \mathrm{du}$ cycle (Gr IV), tandis que les pulses d'OT coïncidant, et ceux apparaissant entre les pics de PGFM, n'étaient jamais supérieurs à $75 \mathrm{pg} / \mathrm{mL}$. Seulement $50 \%$ des pulses d'OT coïncidaient avec des pulses de PGFM, et $54 \%$ des pulses de PGFM coïncidaient avec un pulse d'OT. Les résultats indiquent que la sécrétion lutéolytique de PGF chez les bovins ne dépend pas directement de I’OT ovarienne. (C) Inra/Elsevier, Paris

ocytocine / progestérone / lutéolyse / prostaglandine F2- $\alpha$ / corps jaune / bovins

\section{INTRODUCTION}

Hormonal processes associated with the initiation of luteolysis in cattle are not completely understood $[34,39]$. Although uterine prostaglandin $\mathrm{F} 2 \alpha$, (PGF) is accepted as the natural luteolysin in cattle [14], the trigger for its secretion remains unknown. It has been suggested that ovarian OT initiates PGF secretion [7], and that this effect depends on the exposure of the endometrium to physiological concentrations of progesterone during dioestrus [ 8 , 17]. In cattle the exposure to progesterone, which lasts for 11-14 days depending upon the length of the oestrous cycle [18], is crucial for uterine synthesis of OT receptors [31]. However, a negative correlation has been demonstrated between concentrations of circulating progesterone and concentrations of uterine oxytocin receptor and hence, the degree of respon- siveness to oxytocin [16]. These data suggest progesterone concentrations should be decreased in order for the uterus to become sensitive to an OT challenge. This is in agreement with data suggesting that ovarian OT may not be essential for initiation of luteolysis in cattle, since depletion of luteal OT by $68-82 \%$ with noradrenaline on days 12 or 16 of the cycle [19] did not affect luteolysis. In addition, the complete blockade of OT receptors with a specific OT antagonist from day 15 until day 22 of the cycle [22], did not affect luteolysis. The aim of this study was to investigate the effect of increasing doses of exogenous OT on PGF secretion on day 17 of the oestrous cycle (the time of luteolysis), and to compare peripheral concentrations of OT produced by these treatments to those resulting from endogenous secretion of this peptide on days 16-19. The PGF metabolite, 13, 14-dihydro-15- 
keto-prostaglandin F2 $\alpha$ (PGFM) was used as an indicator of PGF secretion in this study.

\section{MATERIALS AND METHODS}

\subsection{Animals and treatment}

The experiments were carried out in accordance with the principles for the care and use of research animals. Mature nulliparous heifers with a palpable corpus luteum (CL) were injected i.m. with $500 \mu \mathrm{g}$ of a PGF analogue, Oestrophan (Spofa) to induce luteolysis. On day 17 after signs of oestrus were observed, catheters were inserted into the aorta abdominalis [20] of each heifer for OT or saline infusion, and into the jugular vein for blood sample collection. The following day, heifers were assigned randomly to one of four experimental groups (Gr): Gr I - 10 IU OT ( $n=4)$; Gr II - 20 IU OT $(n=4)$; Gr III - 50 IU OT $(n=4)$; Gr IV -control. Blood samples were collected every $10 \mathrm{~min}$ for $1 \mathrm{~h}$ before infusion of OT, followed by collection every $5 \mathrm{~min}$ for $30 \mathrm{~min}$, and every $10 \mathrm{~min}$ for a further $1 \mathrm{~h}$ after OT infusion. Oxytocin (Richter, Hungary) was infused in $5 \mathrm{~mL}$ of saline, followed by $5 \mathrm{~mL}$ of saline to flush the cannula.

In Gr IV ( $n=5)$ jugular blood samples were collected every $15 \mathrm{~min}$ for $12 \mathrm{~h}$, from 0800 to 2000 hours, on days 16-19 of the oestrous cycle to characterize PGF and OT secretion during spontaneous luteolysis. Clotting of blood samples $(8 \mathrm{~mL})$ was prevented by the addition of $76-\mu \mathrm{M}$ EDTA and $11-\mu \mathrm{M}$ acetylsalicylic acid.

\subsection{Radioimmunoassays}

Concentrations of PGFM were determined as described by Homanics and Silvia [11] and the antiserum (WS4468 BD 6/23-7/21) was characterized by the same authors. Sensitivity of the assay was $12 \mathrm{pg} /$ tube. Intra- and interassay coefficients of variation (C.V.) calculated for three different concentrations of control plasma samples included in five repetitions in each assay were 5.6 and $9.0 \%$, respectively. Plasma concentrations of progesterone were determined by a method validated in this laboratory [20] using a rabbit progesterone antiserum $\left(\mathrm{IFP}_{4}\right)$ characterized previously [21]. The sensitivity of the procedure was $15 \mathrm{pg} /$ tube $(0.3 \mathrm{ng} / \mathrm{mL}$ of plasma). Intra- and inter-assay C.V. were 8.1 and $15.9 \%$, respectively. The relationship between real $(x)$ and determined (y) amounts of four different concentrations of progesterone added to plasma samples is expressed by the linear regression equation $(y=1.034 x-0.13)$. Oxytocin was extracted from plasma using a 3 -fold excess of ice-cold acetone. Rabbit OT antiserum (R-1) was characterized previously [19]. The efficiency of extraction was $85 \%$, and final data were corrected for procedural losses. The sensitivity of the method was $1.3 \mathrm{pg} /$ tube $(3 \mathrm{pg} / \mathrm{mL})$. Intraand inter-assay C.V. were 7.5 and $14.6 \%$, respectively. Precision of the procedure based on four different concentrations of added mass is expressed by the linear regression equation $(y=0.99 x+0.14)$. Estradiol-17 $\beta$ was extracted from $1 \mathrm{~mL}$ of plasma using $5 \mathrm{~mL}$ of diethyl ether and RIA was performed using rabbit antiserum (BSz/88/754) characterized by Szafranska and Tilton [40]. Efficiency of extraction was above $80 \%$ and data were corrected for the procedural losses. Sensitivity of the method was $2 \mathrm{pg} / \mathrm{mL}$ and the intra- and interassay C.V. were 5.5 and $11.2 \%$, respectively.

\subsection{Data analysis}

Magnitude of a PGFM response after OT infusion was defined as the maximum concentration of metabolite above baseline during the 1.5-h post-injection period. Baseline was defined as the average concentration of PGFM before injection of oxytocin. Pulses of PGFM and OT in heifers from Gr IV were identified by means of the Pulsar program of Merriam and Wachter [27] as modified for the personal computer by Gitzen and Ramirez [9]. Quadratic, linear and constant terms for calculating assay SD in Pulsar and G(n) values for defining pulses were the same as given earlier [38]. The relationship between OT and PGFM pulses were determined by calculating the number of pulses that appeared either concomitantly or within $1 \mathrm{~h}$ of the start of a pulse of another hormone. 


\section{RESULTS}

Infusion of 10 or $20 \mathrm{IU}$ of OT increased peripheral concentrations of this peptide to about 200 and $350-500 \mathrm{pg} / \mathrm{mL}$, respectively, within $5 \mathrm{~min}$ of infusion; however, neither dose of OT affected PGFM concentrations (figure I). When $50 \mathrm{IU}$ of OT were given, an increase of OT to $1500 \mathrm{pg} / \mathrm{mL}$ in peripheral circulation was observed. This increase in OT caused PGFM concentrations to increase $(P<0.01)$ from basal levels $(35-65 \mathrm{pg} / \mathrm{mL})$ to $100-150 \mathrm{pg} / \mathrm{mL}$ within 10-30 min (figure 1). Concentrations of progesterone during the experiment fluctuated and ranged from 2 to 6 $\mathrm{ng} / \mathrm{mL}$ in heifers in groups I-III. Amplitude of the PGFM peak after OT treatment was independent $(P>0.05)$ of progesterone concentration in individual heifers.

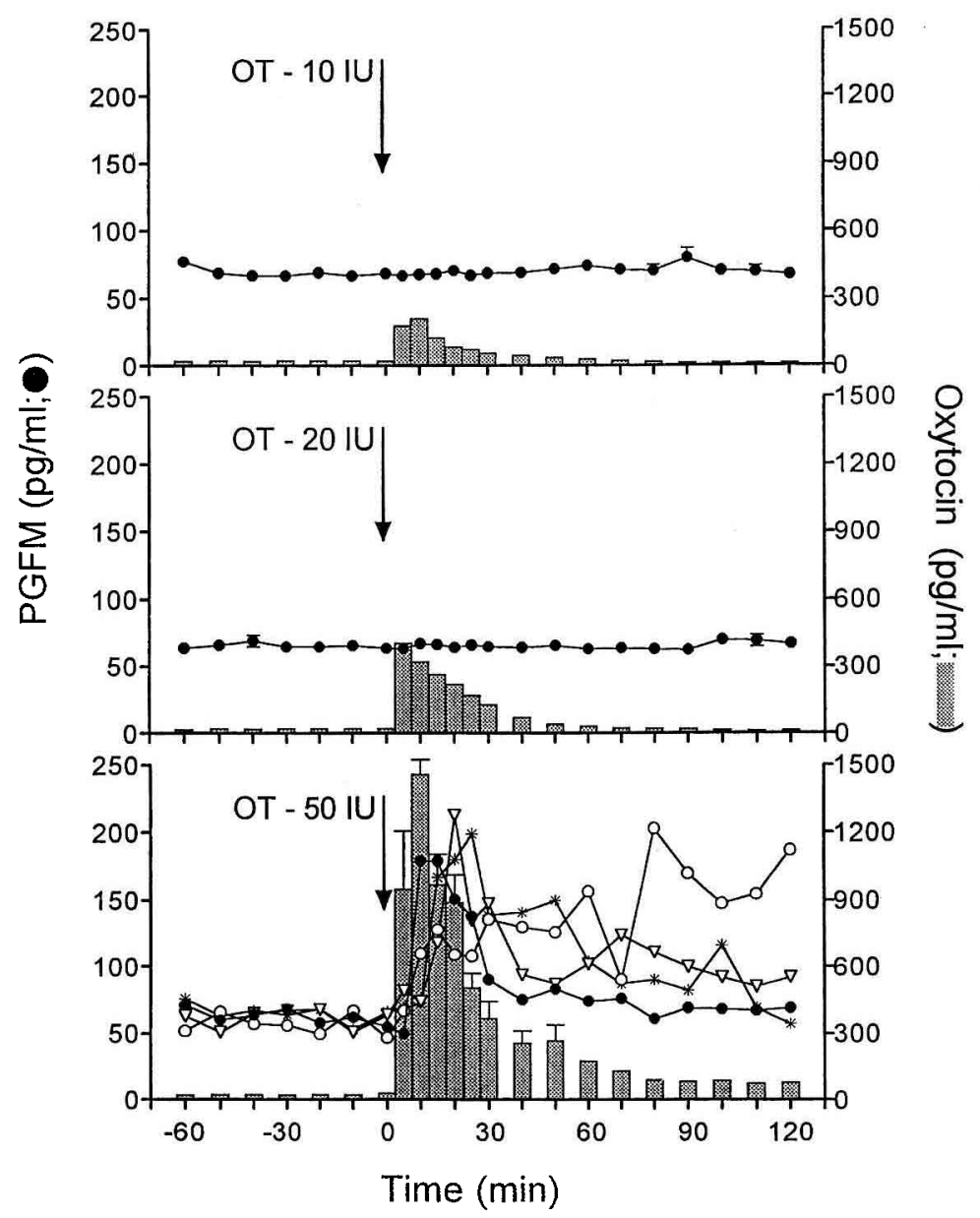

Figure 1. Influence of bolus infusion of $10(n=4), 20(n=4)$, and $50 \mathrm{IU}(n=4)$ of oxytocin (OT) into the aorta abdominalis on peripheral plasma concentrations of PGFM (mean \pm s.e.m.) on day 17 of the oestrous cycle in heifers. PGFM concentrations after 50 IU of OT are given individually for each of four heifers due to varying temporal responses. Progesterone concentrations in these heifers fluctuated and ranged from 6 to $2 \mathrm{ng} / \mathrm{mL}$. 
During spontaneous luteolysis in heifers of Gr IV, pulses of PGFM ranged between 250 and $600 \mathrm{pg} / \mathrm{mL}$, depending upon day of the cycle. Coincident pulses of OT, and those which appeared between peaks of PGFM on days 16-19 of the cycle, never exceeded $75 \mathrm{pg} / \mathrm{mL}$ (figures 2 and 3) When jugular blood samples were collected at frequent intervals on days 16-19 of the cycle, $48 \%$ of all PGFM pulses occurred within the sampling interval of a pulse of OT, and $73 \%$ of OT pulses were coincident with pulses of PGFM. Thus, many pulses of one hormone were in the absence of the other. The total number of OT and PGFM pulses in the heifers studied was 15 and 23, respectively. Moreover, it should be noted that four PGFM pulses followed the OT peak and four OT pulses were observed after PGFM surges.

\section{DISCUSSION}

To significantly stimulate PGF secretion (as determined by analysis of PGFM) by means of exogenous OT, it was necessary to increase peripheral OT concentrations to about $1500 \mathrm{pg} / \mathrm{mL}$ as shown in Gr III, and to even greater concentrations in a study reported by Howard and Britt [13]. This is over 20 times greater than physiological levels of this peptide in cattle ([22, 36]; current study). When OT plasma concentrations exceeded 4-8 times normal values (figure 1) after treatment with 10 or 20 IU, a PGFM response was not observed.

It has been suggested that uterine PGF secretion is switched on by ovarian OT $[7,39]$. However, as long as plasma progesterone concentrations are high, OT receptors may not be replenished $[16,28]$ and in fact, specific binding sites for OT in the bovine corpus luteum are lowest on days 15-18 of the oestrous cycle [32]. Furthermore, analysis of OT and OT mRNA contents of bovine corpus luteum show that little or no OT or OT mRNA is present during luteolysis $[4,15,24]$. Therefore the larger amount of ovarian OT present in the early and mid-luteal phases may be rather luteotrophic in cattle, as found using a microdialysis system [29]. Thus, it can be assumed that an increase in uterine OT receptor numbers should be preceded by a decrease in progesterone concentrations and this rather precludes a controlling influence of luteal OT on the initiation of luteolysis.

On days 13-16 of the oestrous cycle in ewes, $96 \%$ of PGFM pulses were observed concomitantly with OT pulses, whereas only $56 \%$ of oxytocin pulses coincided with pulses of PGFM if uteroovarian vein blood was collected [12]. These authors concluded that OT stimulates uterine PGF secretion and not vice versa. A similar relationship between OT and PGF was found in ewes by Burgess et al. [2]. However, this conclusion omits the fact that over $44 \%$ of OT pulses from the ovary do not produce a pulse of PGF from the uterus. Furthermore other groups working with sheep have found opposite results. Moore et al. [30] observed that concentrations of PGFM in the utero-ovarian vein effluent increased before any increase was observed in secretion of OT during frequent bleeding. This observation agrees with data by Silvia and Raw [38] who found that frequency of PGFM pulses in ovariectomized ewes could be completely restored without OT support. However, the lower PGFM pulses observed in their studies may suggest that OT amplifies the course of induced luteolysis as a regulator of the amplitude of pulsatile PGF secretion, as shown in heifers [23].

In the present study, 27 and $52 \%$ of pulses of OT and PGFM, respectively, were released without concomitant secretion of the other hormone during 12-h periods in Gr IV (figures 2 and 3). Very similar data were obtained in recent studies 


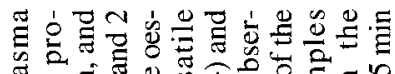

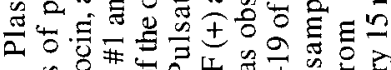

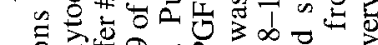
i.

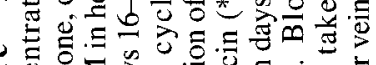

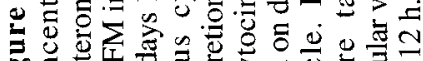

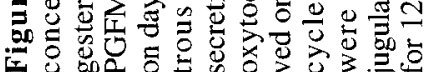

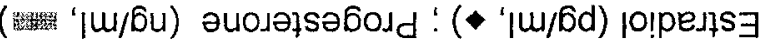
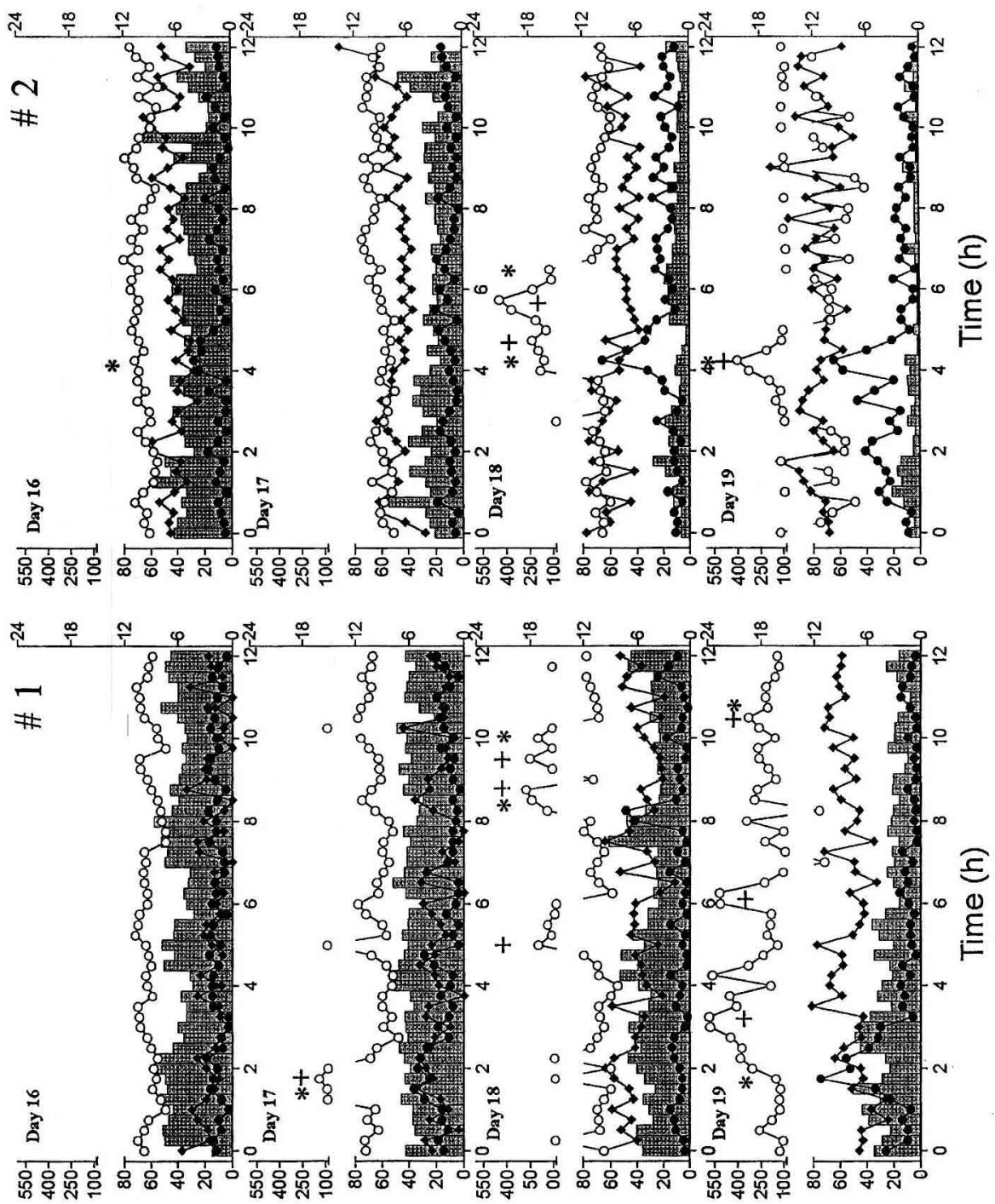

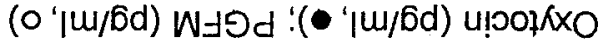




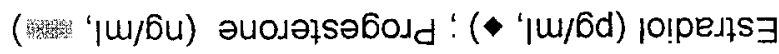
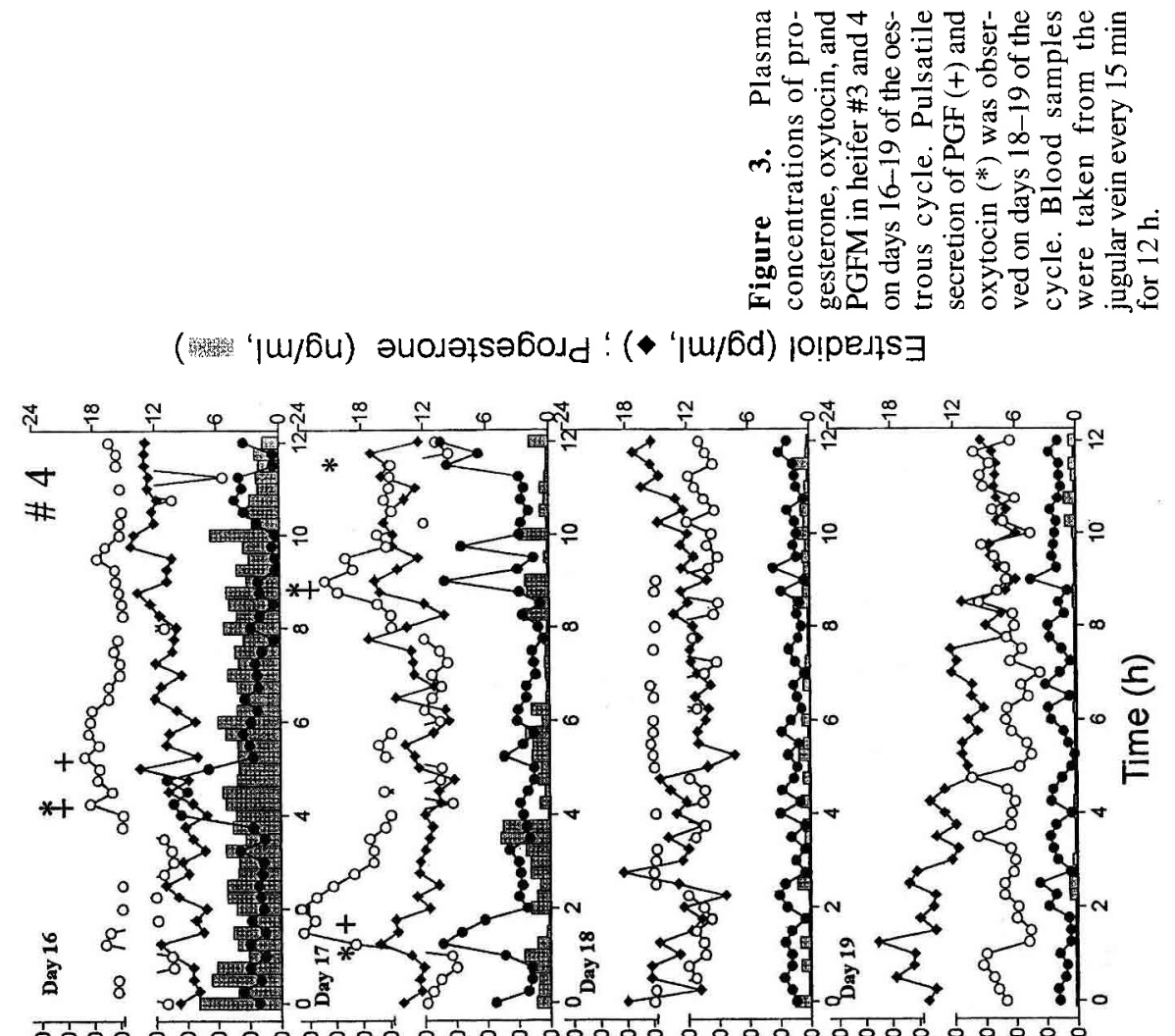

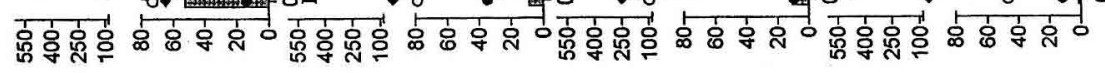

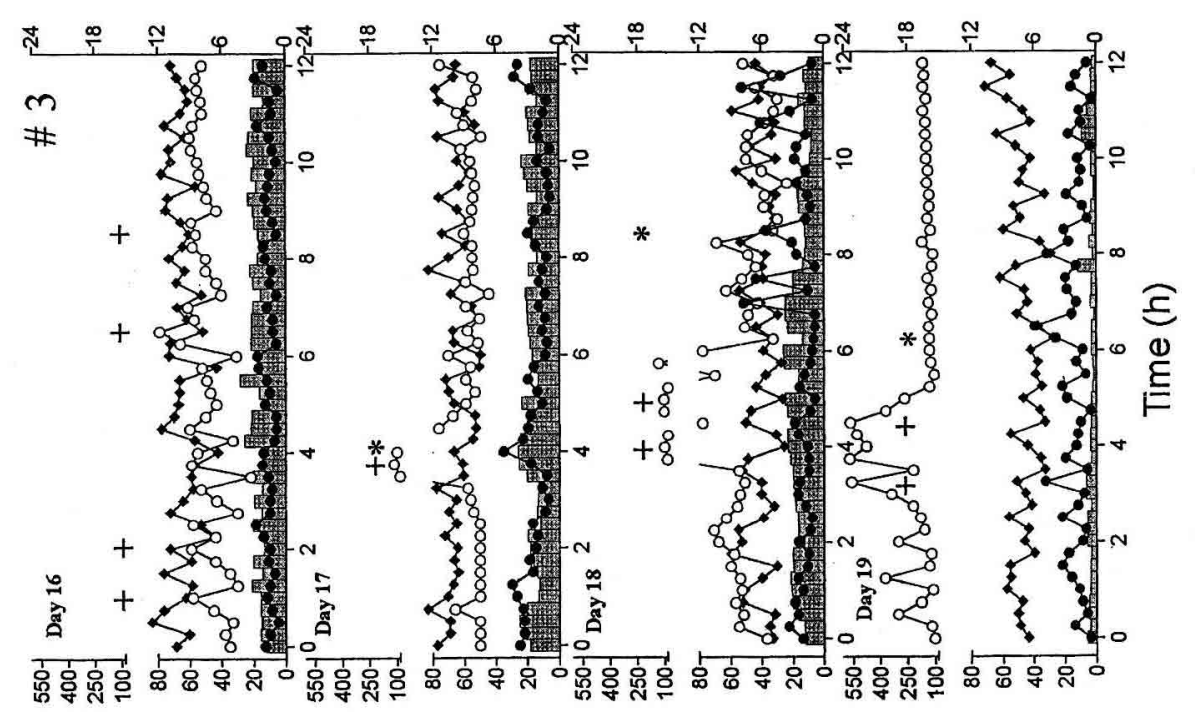

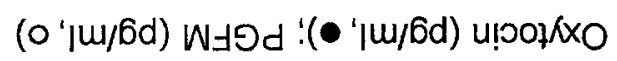


[22]. Observations by Fields et al. [5] also seem to agree with these results. They showed that from days 7-14 there was a $69 \%$ decline in the number of large cells containing oxytocin-laden secretory granules in the cow. This occurred before the synthesis of uterine OT receptors and luteolytic pulses of PGF. These results help to explain why depletion of OT from the bovine CL by up to $82 \%$ on days 12 or 16 of the oestrous cycle did not affect the time of luteolysis [19]. It can be assumed that even less than $20 \%$ of OT may be enough to induce luteolysis. However, to prove that OT affects PGF secretion it was necessary to treat cow with 20-100 IU of OT $[13,25]$. Moreover, continuous blockade of OT receptors in heifers from day 15 until oestrus did not affect luteolysis compared to control [22]. This supports recent data $[1,10]$ which demonstrated that luteal regression can occur in the absence of OT release from the luteal cells.

Collectively, these and other data seem to disagree with the theory that ovarian OT can trigger uterine PGF secretion and initiate luteolysis in cattle. Previously, it was observed that continuous infusion of OT in sheep blocked the synthesis of OT receptors [6]. However, injection of a PGF analogue during OT infusion caused a rise in OT receptors to values comparable to those in control animals. Thus, it is possible that during spontaneous luteolysis, PGF either decreases progesterone concentrations, allowing OT receptors to increase, or it stimulates OT receptor synthesis directly as suggested by Chan et al. [3] and by Sheldrick and Flick-Smith [37].

Data by Homanics and Silvia [11] and Lamming et al. [26] indicate that progesterone pre-treatment of sheep for over 10 days stimulates PGF synthesis and secretion. Furthermore, they suggest that the length of progesterone exposure controls the timing for the down-regulation of uterine progesterone receptors which, in turn, controls OT receptors. Similarly, studies in cattle $[8,17]$ have shown that duration of exposure to progesterone at concentrations above $2 \mathrm{ng} / \mathrm{mL}$ plays an important role in controlling the appearance of PGF pulses. Usually, the period of progesterone dominance in cattle lasts 11-14 days, depending upon oestrous cycle duration. Parkinson and Lamming [33] have observed pulses of PGF in cattle, theoretically of luteal origin [35], 2-3 days before the drop in progesterone concentrations in blood at luteolysis. Thus, it can be hypothesized that the influence of progesterone in controlling the secretion of low level PGF pulses occurs well-before the time of luteolysis, as assumed earlier [3, 11].

In conclusion, results of the current study indicate that the initiation of luteolytic PGF secretion in cattle is not directly dependent upon ovarian OT, as has been suggested in sheep. However, these observations do not exclude a possible involvement of ovarian OT in a luteolytic process already underway. Influence of OT on amplitude of PGF pulses [23] may be such an example. Thus, OT may be only one of a mixture of physiological factors involved in the start of functional luteolysis.

\section{ACKNOWLEDGEMENTS}

We thank S. Okrasa and G. Kotwica (University of Agriculture and Technology, Olsztyn, Poland) and W.J. Silvia (University of Kentucky, Lexington, USA) for providing antiserum against progesterone, oxytocin and PGFM, respectively. We are indebted to $M$. Niedzwiedzki (Private Farm, Mortegi) for excellent co-operation and Dr Y. Tillet (Inra, Tours) for the French translation. This study was supported by a grant (MR/USDA-92-94) to J.K. and G.L.W. Part of these results were presented during SSR Winter Conference (Aachen, Germany, 17-18 December 1993). 


\section{REFERENCES}

[1] Blair R.M., Saatman R., Liou S.S., Fortune J.E., Hansel W., Roles of leukotrienes in bovine corpus luteum regression: an in vivo microdialysis study, Proc. Soc. Exp. Biol. Med. 216 (1997) 72-80.

[2] Burgess K.M., Ralph M.M., Jenkin G., Thorburn G.D., Effect of oxytocin and estradiol on uterine prostaglandin release in nonpregnant and early-pregnant ewes, Biol. Reprod. 42 (1990) 822-833.

[3] Chan W.Y., Berezin I., Daniel E.E., Effects of inhibition of prostaglandin synthesis on uterine oxytocin receptor concentration and myometrial gap junction density in parturient rats, Biol. Reprod. 39 (1988) 1117-1128.

[4] Fehr S., Ivell R., Koll R., Schams D., Fields M., Richter D., Expression of the oxytocin gene in the large cells of the bovine corpus luteum, FEBS Lett. 210 (1987) 45-50.

[5] Fields M.J., Barros C.M., Watkins W.B., Fields P.A., Characterization of large luteal cells and their secretory granules during the estrous cycle of the cow, Biol. Reprod. 46 (1992) 535-545.

[6] Flint A.P.F., Sheldrick E.L., Continuous infusion of oxytocin prevents induction of uterine oxy tocin receptor and blocks luteal regression in cyclic ewes, J. Reprod. Fert. 75 (1985) 623-631.

[7] Flint A.P.F., Sheldrick E.L., Ovarian oxytocin and maternal recognition of pregnancy, J. Reprod. Fert. 76 (1986) 831-839.

[8] Geisert R.D., Short E.C., Zavy M.T., Maternal recognition of pregnancy, Anim. Reprod. Sci. 28 (1992) 287-298.

[9] Gitzen J.F., Ramirez V.D., PC-Pulsar (Pulsar pulse analysis for the IBM-PC), Life Sci. 38 (1986) III.

[10] Hansel W., Blair R.M., The role of lipoxygenase products of arachidonic acid metabolism in bovine corpus luteum function, Reprod. Dom. Anim. 31 (1996) 427-429.

[11] Homanics G.E., Silvia W.J., Effects of progesterone and estradiol-17B on uterine secretion of prostaglandin $F 2 \alpha$ in response to oxytocin in ovariectomized ewes, Biol. Reprod. 38 (1988) 804-811.

[12] Hooper S.B., Watkins W.B., Thorburn G.D., Oxytocin, oxytocin associated neurophysin and prostaglandin $\mathrm{F} 2 \alpha$ concentrations in the utero-ovarian vein of pregnant and non-pregnant sheep, Endocrinology 119 (1986) 2590-2597.

[13] Howard H.J., Britt J.H., Prostaglandin-F metabolite after exogenous oxytocin in cows given hCG during diestrus, Biol. Reprod. 36 (1987) (suppl. 1) 274 (abstract).
[14] Inskeep E.K., Potential uses of prostaglandins in control of reproductive cycles of domestic animals, J. Anim. Sci. 36 (1986) 1149-1157.

[15] Ivell R., Brackett H., Fields M.J., Richter D., Ovulation triggers oxytocin gene expression in the bovine ovary, FEBS Lett. 190 (1985) 263-267.

[16] Jenner L.J., Parkinson T.J., Lamming G.E., Uterine oxytocin receptors in cyclic and pregnant cows, J. Reprod. Fert. 91 (1991) 49-58.

[17] Kotwica J., Participation of ovarian oxytocin in the oestrous cycle regulation in cattle, Acta Acad. Agricul. Tech. Olst. 31 (suppl. C) (1988) 1-56 (in Polish).

[18] Kotwica J., Williams G.L., Relationship of plasma testosterone concentrations to pituitary-ovarian hormone secretion during the bovine estrous cycle and the effects of testosterone propionate administered during luteal regression, Biol. Reprod. 27 (1982) 790-801.

[19] Kotwica J., Skarzynski D., Influence of oxytocin removal from corpus luteum on secretory function and duration of the oestrous cycle, J. Reprod. Fert. 97 (1993) 411-417.

[20] Kotwica J., Skarzynski D., Jaroszewski J., Coccygeal artery as a route for the administration of drugs into the reproductive tract of cattle, Vet. Rec. 127 (1990) 38-40.

[21] Kotwica J., Skarzynski D., Jaroszewski J., Bogacki M., Noradrenaline affects secretory functions of corpus luteum independently of prostaglandins in conscious cattle, Prostaglandins 48 (1994) 1-10.

[22] Kotwica J., Skarzynski D., Bogacki M., Melin P., Starostka B., The use of an oxytocin antagonist to study the function of ovarian oxytocin during luteolysis in cattle, Theriogenology 48 (1997) 1287-1299.

[23] Kotwica J., Skarzynski D., Bogacki M., Melin P., Okuda K., Oxytocin modulates the pulsatile secretion of prostaglandin $\mathrm{F} 2 \alpha$ in initiated luteolysis in cattle, Res. Vet. Sci. (1998) (accepted).

[24] Kruip T.A.M., Vullings K.G.B., Schams D., Jonis J., Klarenbach A., Immunocytovhemical demonstration of oxytocin in bovine ovarian tissue, Acta Endocrinol. 109 (1985) 537-542.

[25] Lafrance M., Goff A.K., Effects of progesterone and oestradiol-17 $\beta$ on oxytocin-induced release of prostaglandin $\mathrm{F}$ in heifers, $\mathrm{J}$. Reprod. Fert. 82 (1988) 429-436.

[26] Lamming G.E., Vallet J.L., Flint A.P.F., Progestational control of endometrial oxytocin receptor determines cycle length in sheep, J. Reprod. Fert. 43 (suppl.) (1989) 53-54. 
[27] Merriam G.R., Wachter K.W., Algorithms for the study of episodic hormone secretion, Am. J. Physiol. 243 (1982) E310-318.

[28] Meyer H.H.D., Mittermeier Th., Schams D., Dynamics of oxytocin, estrogen and progestin receptors in the bovine endometrium during the estrous cycle, Acta Endocrinol. 118 (1988) 96-104.

[29] Miyamoto A., Schams D., Oxytocin stimulates progesterone release from microdialyzed bovine corpus luteum in vitro, Biol. Reprod. 44 (1991) 1163-1170.

[30] Moore L.G., Choy V.J., Elliot R.L., Watkins W.B., Evidence for the pulsatile release of $\mathrm{PGF}_{2 \alpha}$ inducing the release of ovarian oxytocin during luteolysis in the ewe, J. Reprod. Fert. 76 (1986) 159-166.

[31] Morgan G.L., Geisert R.D., McCann J.P., Bazer F.W., Ott T.L., Mirando M.A., Stewart M., Failure of luteolysis and extension of the interoestrous interval in sheep treated with the progesterone antagonist mifepristone (RU 486), J. Reprod. Fert. 98 (1993) 451-457.

[32] Okuda K., Miyamoto A., Sauerwein H., Schweigert F.J., Schams D., Evidence for oxytocin receptors in cultured bovine luteal cells, Biol. Reprod. 46 (1992) 1001-1006.

[33] Parkinson T.J., Lamming G.E., Interrelationship between progesterone, 13,14-dihydro-15-keto PGF-2 $\alpha$ (PGFM) and LH in cyclic and early pregnant cows, J. Reprod. Fert. 90 (1990) 221-233.
[34] Pickering B.T., Ayad V.J., Birkett S.D., Gilbert C.L., Guldenaar S.E.F., Nicholson H.D., Worley R.T.S., Wathes D.C., Neurohypophysial peptides in the gonads: are they real and do they have a function? Reprod. Fert. Dev, 2 (1992) 245-262.

[35] Rothchild I. The regulation of the mammalian corpus luteum, Rec. Prog. Horm. Res. 37 (1981) 183-283.

[36] Schams D., Schallenberger E., Meyer H.H.D., Bullermann B., Breitinger H.J., Koll R., Enzenhofer G., Kruip T.A.M., Walters D.L., Karg H. Ovarian oxytocin during estrous cycle in cattle, in: Amico J.A., Robinson A.G. (Eds.), Oxytocin, Clinical and Laboratory Studies, Elsevier Biomedical, Amsterdam, 1985, pp. 317-334.

[37] Sheldrick E.L., Flick-Smith H.C., Effect of ovarian hormones on oxytocin receptor concentrations in explants of uterus from ovariectomized ewes, J. Reprod. Fert. 97 (1993) 241-245.

[38] Silvia W.J., Raw R.E., Regulation of pulsatile secretion of prostaglandin F2 $\alpha$ from the ovine uterus by ovarian steroids, J. Reprod. Fert. 98 (1993) 341-347.

[39] Silvia W.J., Lewis G.L., McCracken J.A., Thatcher W.W., Wilson J., Hormonal regulation of uterine secretion of prostaglandin $\mathrm{F}_{2 \alpha}$ during luteolysis in ruminants, Biol. Reprod. 45 (1991) 655-663.

[40] Szafranska B., Tilton J.E., Prolactin as luteotrophin during late pregnancy in pigs, J. Reprod. Fert. 98 (1993) 643-648. 